\title{
Insulin resistance metabolomic profile in non-diabetic women with systemic lupus erythematosus
}

\author{
Claudia Mendoza-Pinto ${ }^{1,2}$, Mario García-Carrasco ${ }^{1,2 *}$, Socorro Méndez-Martínez ${ }^{3}$, Pamela Munguía- \\ Realpozo ${ }^{1}$, Ivet Etchegaray-Morales', Gerardo Díaz-Merino', Pamela Soto-Santillán', Marco A. Escamilla- \\ Márquez $z^{4}$ and Alejandro Ruiz-Arguelles ${ }^{5}$ \\ ${ }^{1}$ Systemic Autoimmune Diseases Research Unit, High Specialty Medical Unit, Centro Médico Nacional Manuel Ávila Camacho-CIBIOR, Instituto \\ Mexicano del Seguro Social; ' ${ }^{2}$ mmunology and Rheumatology Department, Faculty of Medicine, Benemérita Universidad Autónoma de Puebla; \\ ${ }^{3}$ Research Coordination, Instituto Mexicano del Seguro Social; ${ }^{4}$ Endocrinology Department, High Specialty Medical Unit, Centro Médico Nacional \\ Manuel Ávila Camacho, Instituto Mexicano del Seguro Social; ${ }^{5}$ Laboratorios Clínicos de Puebla. Puebla, Mexico
}

\begin{abstract}
Introduction: Patients with systemic lupus erythematosus (SLE) have a higher prevalence of insulin resistance (IR) and metabolic syndrome (MetS) than controls. Objective: To evaluate IR in non-diabetic women with SLE by means of biomarkers using high-throughput metabolomic techniques. Method: Cross-sectional study in patients with SLE. A metabolomic approach was employed using ultra-high performance liquid chromatography coupled with high-resolution mass spectrometry. MetS was evaluated according to NCEP-ATP III criteria. Results: Seventy patients with SLE were included, out of whom 45 (64.2\%) and 27 (38.5\%) had IR and MetS, respectively. Patients with IR had a higher body mass index and hypertension more often than those without IR. Chronic damage and disease activity were not related to IR. A Quantose-IR score $\geq 63$ was more common in patients with MetS (81.5 vs. 53.5\%; $p=0.02$ ). Quantose-IR score was also correlated with the number of criteria for MetS ( $r: 0.35$; $p=0.003)$. Conclusions: In non-diabetic women with SLE, the prevalence of IR based on Quantose-IR score was 64.2\%.
\end{abstract}

KEY WORDS: Systemic lupus erythematosus. Insulin resistance. Metabolomics.

\section{Perfil metabolómico de resistencia a la insulina en mujeres no diabéticas con lupus eritematoso sistémico}

\section{Resumen}

Introducción: En lupus eritematoso sistémico (LES) es más frecuente la prevalencia de resistencia a la insulina (RI) y síndrome metabólico (SMet) que en controles. Objetivo: Evaluar la RI en mujeres no diabéticas con LES mediante biomarcadores usando técnicas metabolómicas de alta resolución. Método: Estudio transversal en pacientes con LES. Se empleó un abordaje metabolómico usando cromatografía de líquidos de ultra-alta resolución con espectrometría de masa de alta resolución. EI SMet fue evaluado de acuerdo con los criterios NCEP-ATP III. Resultados: Se incluyeron 70 pacientes con LES. Tuvieron RI y SMet 45 (64.2\%) y 27 (38.5\%), respectivamente. Pacientes con RI tenían un mayor índice de masa corporal e hipertensión con mayor frecuencia que aquellas sin RI. El daño crónico y la actividad de la enfermedad no se relacionaron con RI. Un puntaje de Quantose $R I \geq 63$ fue más elevado en pacientes con SMet (81.5 vs 53.5\%; $p=0.02)$. El puntaje Quantose $R I$ también se correlacionó con el número de criterios para SMet ( $r: 0.35 ; p=0.003)$. Conclusiones: En mujeres con LES no diabéticas, la prevalencia de RI basada en el puntaje de Quantose RI fue del $64.2 \%$.

PALABRAS CLAVE: Lupus eritematoso sistémico. Resistencia a la insulina. Metabolómica.

\footnotetext{
Correspondence:

Date of reception: $14-04-2021$

*Mario García-Carrasco

Date of acceptance: 11-10-202

E-mail: cmp_26@yahoo.com.mx

DOI: $10.24875 / G M M . M 21000622$

Gac Med Mex. 2021;157:594-598

Contents available at PubMed license (http://creativecommons.org/licenses/by-nc-nd/4.0/).
} 


\section{Introduction}

Recently, a possible association between systemic lupus erythematosus (SLE) and high rates of insulin resistance (IR) measured by the Homeostatic Model Assessment-Insulin Resistance (HOMA-IR) insulin resistance index ${ }^{1,2}$ and metabolic syndrome (MetS) ${ }^{3}$ has become a topic of interest. IR, defined as insulin-sensitive tissues decreased sensitivity or receptivity to insulin ${ }^{4}$, has been shown to be an independent risk factor for type 2 diabetes mellitus (T2DM) ${ }^{5}$, and can be present for years before the appearance of any changes in glycemic control. HOMA-IR index is a simple model that requires a single blood sample, but it is not clear whether it offers advantages over fasting insulin ${ }^{6}$. Therefore, there is a need for a simple method to measure IR that can be used for systematic screening, prospective studies, risk assessment, therapeutic monitoring, and that is cost-effective for adequate follow-up. Metabolomics is an emerging analytical technology that simultaneously quantifies multiple metabolites in biological fluids and identifies new biomarkers that are highly discriminatory for biological alterations ${ }^{7}$. Ultra-high performance liquid chromatography with high resolution mass spectrometry (UHPLC-HRMS) is considered an adequate tool for metabolite identification and metabolomic study, especially for large-scale indeterminate metabolic identification, due to its separation efficiency ${ }^{8,9}$.

Although metabolomics has shown potential in the diagnosis of SLE ${ }^{10}$ and lupus nephritis ${ }^{11}$, serum metabolomics has not yet been studied for identifying the metabolic alterations associated with IR in these patients. Therefore, the purpose of this study is to study IR in non-diabetic women with SLE using a high-throughput metabolomic technique, as well as to evaluate the relationship between traditional and SLE risk factors and the presence of IR.

\section{Methods}

In this cross-sectional study with approval of the Local Ethics Committee, adult patients with SLE according to the American College of Rheumatology $(A C R)^{12}$ criteria without cardiovascular events (CVE) were included. Patients with DM, CVE, obesity or pregnant women were excluded. The patients were evaluated for cardiovascular risk factors and current treatment (current glucocorticoids and within last six months), anthropometry and blood pressure. SLE activity and chronic damage were measured with the SLE Disease Activity Index 2000 (SLEDAI-2K) ${ }^{13}$ and the Systemic Lupus International Collaborating Clinics (SLICC)/ACR index ${ }^{14}$, respectively. MetS was determined using the National Cholesterol Education Program- Adult Treatment Panel III (NCEP-ATP III) criteria $^{15}$.

UHPLC-HRMS uses the stable isotope dilution technique to quantify hydroxybutyric acid (HBA), L-linoleoyl-glycerophosphocholine (LGPC), and oleate (Waters Acquity UHPLC System, Waters Corporation, Milford, MA); HBA, LGPC and oleic acid were eluted with a gradient on a Waters Acquity single RP C-18 column (2.1 $\mathrm{mm} \times 50 \mathrm{~mm}, 1.7-\mathrm{mm}$ particle size) at a flow rate of $0.8 \mathrm{~mL} / \mathrm{min}$ at $40{ }^{\circ} \mathrm{C}$. Ionization was achieved using a heated electrospray ionization source. Quantification was based on the relationships of the substance area and internal standard peaks using a weighted least squares linear regression analysis, generated from fortified calibration standards in an artificial matrix, prepared before each analytical series. Plasma insulin was quantified using Abbott chemiluminescent microparticle immunoassay (Architect). Concentrations of the substances were used in conjunction with an algorithm to calculate the IR level with the Quantose IR ${ }^{\text {TM }}$ score $^{8}$. The IR cutoff value of 63 was defined by the European study scores upper tertile ${ }^{16}$.

For statistical analysis, quantitative variables were evaluated with Student's t-test or Mann-Whitney's U-test, and categorical variables with the chi-square test. Spearman's correlation was used to evaluate the relationship between the number of MetS criteria and the Quantose RI score. SPSS statistical program for Mac, version 25.0 (SPSS Inc., Chicago, IL, USA), was used.

\section{Results}

Seventy patients with SLE with an age of $39.3 \pm$ 10.6 years were included. Table 1 shows the sociodemographic data and disease-related characteristics. Forty-five of the 70 patients (64.2\%) with SLE had IR with a median Quantose IR score of 69 (interquartile range [IQR]: 52.7-80.0).

The prevalence of IR was higher in patients with MetS in comparison with those without NCEP-ATP III criteria (81.5 vs. $53.5 \%$; $p=0.02$ ).

The number of MetS criteria was correlated with Quantose IR score ( $r: 0.35 ; p=0.003$ ). Body mass index (BMI) and insulin were higher in patients with 
Table 1. Characteristics of the 70 patients with systemic lupus erythematosus

\begin{tabular}{|c|c|}
\hline & Measurement \\
\hline $\begin{array}{l}\text { Age, years } \\
\text { Mean (SD) }\end{array}$ & $39.3 \pm 10.6$ \\
\hline $\begin{array}{l}\text { Disease duration, years } \\
\text { Median (IQR) }\end{array}$ & $11(8-14)$ \\
\hline $\begin{array}{l}\mathrm{BMl}, \mathrm{kg} / \mathrm{m}^{2} \\
\text { Mean (SD) }\end{array}$ & $26.3 \pm 24.2$ \\
\hline $\begin{array}{l}\text { Waist circumference, } \mathrm{cm} \\
\text { Mean (SD) }\end{array}$ & $89.5 \pm 11.5$ \\
\hline $\begin{array}{l}\text { Obesity } \\
\mathrm{n}(\%)\end{array}$ & $12(17.1)$ \\
\hline $\begin{array}{l}\text { Systolic blood pressure, } \mathrm{mmHg} \\
\text { Mean (SD) }\end{array}$ & $119.5 \pm 12.2$ \\
\hline $\begin{array}{l}\text { Diastolic blood pressure, } \mathrm{mmHg} \\
\text { Mean (SD) }\end{array}$ & $76.4 \pm 9.7$ \\
\hline $\begin{array}{c}\text { Smokers } \\
\mathrm{n}(\%)\end{array}$ & $5(7.1)$ \\
\hline $\begin{array}{l}\text { Menopause } \\
\mathrm{n}(\%)\end{array}$ & $69(43.1)$ \\
\hline $\begin{array}{l}\text { Hypertension } \\
\mathrm{n}(\%)\end{array}$ & $24(24.3)$ \\
\hline $\begin{array}{l}\text { Glucose, } \mathrm{mg} / \mathrm{dL} \\
\text { Mean (SD) }\end{array}$ & $91 \pm 17.4$ \\
\hline $\begin{array}{l}\text { Total cholesterol, mg/dL } \\
\text { Mean (SD) }\end{array}$ & $191.6 \pm 37.6$ \\
\hline $\begin{array}{l}\text { Triglycerides, mg/dL } \\
\text { Mean (SD) }\end{array}$ & $162.7 \pm 111.4$ \\
\hline $\begin{array}{l}\text { HDL-cholesterol mg/dL, } \\
\text { Mean (SD) }\end{array}$ & $49.0 \pm 16.4$ \\
\hline $\begin{array}{l}\text { Family history of CVE, } n(\%) \\
n(\%)\end{array}$ & 27 (38.6) \\
\hline $\begin{array}{l}\text { SLEDAI-2K, score } \\
\text { Mean (SD) }\end{array}$ & $0.8 \pm 1.5$ \\
\hline $\begin{array}{l}\text { Anti-dsDNA, positive } \\
n(\%)\end{array}$ & $12(17.1)$ \\
\hline $\begin{array}{r}\mathrm{SDI} \geq 1 \\
\mathrm{n}(\%)\end{array}$ & $12(17.4)$ \\
\hline $\begin{array}{l}\text { Glucocorticoids, use } \\
\text { n (\%) }\end{array}$ & $64(91.4)$ \\
\hline $\begin{array}{l}\text { Prednisone current daily dose, mg/d } \\
\text { Mean (SD) }\end{array}$ & $10.0 \pm 9.0$ \\
\hline $\begin{array}{l}\text { Glucocorticoid 6-month cumulative dose, g } \\
\text { Mean (SD) }\end{array}$ & $1.8 \pm 1.5$ \\
\hline $\begin{array}{l}\text { Antimalarial drugs, } n \\
n(\%)\end{array}$ & $48(68.6)$ \\
\hline $\begin{array}{l}\text { Immunosuppressive drugs, } \mathrm{n} \\
\mathrm{n}(\%)\end{array}$ & $39(55.7)$ \\
\hline $\begin{array}{l}\text { Statins } \\
\mathrm{n}(\%)\end{array}$ & $18(25.7)$ \\
\hline
\end{tabular}

higher Quantose IR scores in comparison with patients with normal Quantose IR (Table 2). Hypertension was significantly more common in the former group. No other significant differences were found in other sociodemographic or clinical variables. There were no differences in current or cumulative glucocorticoids (GCC) dose between patients with or without IR either.

\section{Discussion}

Our results confirm that IR is common in SLE, as demonstrated by novel metabolic markers of diabetes risk. The biochemical profile based on mass spectrometry is an emerging technological approach to identify biomarkers that can serve as metabolic markers and as a basis for novel diagnostic tests $7,17,18$, as demonstrated in a previous study for its usefulness for SLE diagnosis ${ }^{11}$. In addition, recent studies have used this technique to identify predictive biomarkers of T2DM future development ${ }^{19}$.

Quantose IR is a test for IR developed and validated within the Relationship between Insulin Sensitivity and Cardiovascular Disease (RISC) study ${ }^{8}$. It has been shown to be useful for predicting the progression from glucose normal tolerance to intolerance and is superior to other simple baseline measurements (fasting insulin, BMI, fasting glucose, HOMA-IR) in this context. The final score was developed to estimate the value obtained from the hyperinsulinemic-euglycemic clamp, the gold standard for determining insulin sensitivity, within a prospective, observational study of a cohort of 1,277 clinically healthy, non-diabetic subjects recruited from 13 European countries ${ }^{20}$. It is the first and only test developed and clinically validated using the clamp.

The present study is the first one to use the Quantose IR test in patients with SLE. Previous studies found that insulin and HOMA-IR levels did significantly increase in patients with SLE in comparison with controls $^{21,22}$. In our study, a Quantose IR score $>63$ was found to be related to some MetS components, such as BMI and hypertension. In addition, Quantose IR was also correlated with the number of MetS criteria; therefore, this tool could be useful for follow-up and monitoring of changes resulting from dietary, behavioral and pharmacological modifications.

Similar findings have recently been reported in multiple sclerosis, and it could be useful for IR to be investigated in chronic autoimmune diseases, since it can complicate the underlying pathology and further impair quality of life ${ }^{23}$. 
Table 2. Characteristics of patients with systemic lupus erythematosus with and without insulin resistance $(n=70)$

\begin{tabular}{|c|c|c|c|}
\hline & \multicolumn{2}{|c|}{ Insulin resistance } & \multirow[t]{2}{*}{ p } \\
\hline & $\begin{array}{c}\text { Quantose }<63 \\
(n=25)\end{array}$ & $\begin{array}{l}\text { Quantose } \geq 63 \\
\quad(n=45)\end{array}$ & \\
\hline Age, years & $41.04 \pm 9.93$ & $38.42 \pm 11.04$ & 0.87 \\
\hline Disease duration, years & $11.04 \pm 5.42$ & $11.73 \pm 7.20$ & 0.52 \\
\hline Menopause, n (\%) & $34(43.0)$ & $35(43.2)$ & 0.55 \\
\hline Family history of CVE, n (\%) & $10(40.0)$ & $17(37.8)$ & 0.52 \\
\hline Active smoking, $n \%$ & $2(8.0)$ & $3(6.7)$ & 0.80 \\
\hline Total physical activity, hours/week & $2.17 \pm 1.48$ & $2.79 \pm 2.30$ & 0.12 \\
\hline $\mathrm{BMI}, \mathrm{kg} / \mathrm{m}^{2}$ & $23.7(21-27)$ & $27(25-30)$ & $<0.01$ \\
\hline Waist circumference, $\mathrm{cm}$ & $85.84 \pm 10.88$ & $91.64 \pm 11.57$ & 0.89 \\
\hline Waist-hip ratio & $0.91 \pm 0.12$ & $0.91 \pm 0.08$ & 0.24 \\
\hline Hypertension, n (\%) & $2(8.0)$ & $15(33.3)$ & 0.02 \\
\hline SLEDAI-2K, score & $1.00 \pm 1.50$ & $0.82 \pm 1.52$ & 0.89 \\
\hline SLICC $\geq 1$ & $7(28.0)$ & $10(22.2)$ & 0.77 \\
\hline Anti-dsDNA-positive, $n(\%)$ & $4(16.7)$ & $8(17.8)$ & 0.59 \\
\hline $\mathrm{C} 3, \mathrm{mg} / \mathrm{dL}$ & $96.23 \pm 21.77$ & $103.74 \pm 24.36$ & 0.45 \\
\hline $\mathrm{C} 4, \mathrm{mg} / \mathrm{dL}$ & $17.56 \pm 8.42$ & $17.50 \pm 8.03$ & 0.80 \\
\hline Prednisone daily dose, $\mathrm{mg}$ & $9.50 \pm 7.39$ & $10.38 \pm 9.89$ & 0.52 \\
\hline Glucocorticoid cumulative dose, $\mathrm{g} / 6$ months & $1.96 \pm 1.75$ & $1.75 \pm 1.42$ & 0.35 \\
\hline Antimalarial drugs, n (\%) & $15(60.0)$ & $33(73.3)$ & 0.29 \\
\hline Immunosuppressant, $\mathrm{n}(\%)$ & $9(36.0)$ & $30(66.7)$ & 0.02 \\
\hline Statins, n (\%) & $5(20.0)$ & $13(28.9)$ & 0.57 \\
\hline Glucose, mg/dL & $90.70 \pm 15.95$ & $92.02 \pm 18.37$ & 0.36 \\
\hline Total cholesterol, mg/dL & $192.96 \pm 36.90$ & $190.92 \pm 38.40$ & 0.75 \\
\hline Triglycerides, mg/dL & $151.92 \pm 86.24$ & $168.73 \pm 123.75$ & 0.73 \\
\hline HDL-C low levels, n (\%) & $3(12.0)$ & $14(31.1)$ & 0.08 \\
\hline Insulin, $\mu \mathrm{U} / \mathrm{L}$ & $5.78 \pm 1.82$ & $14.26 \pm 8.62$ & $<0.01$ \\
\hline
\end{tabular}

The present study has some limitations. First, measurements were carried out on a single occasion; therefore, misclassification of the possible risk factors could have affected our estimates; in addition, the absence of a healthy control group limits obtaining a comparative frequency of our results. Second, our study was only comparative, exploratory; studies with a larger sample size allowing a multivariate analysis to be carried out, controlling for confounding factors, would be required. Third, there are uncertainties that could restrict the extrapolation of our findings to other SLE patients with higher disease activity, since most our patients had mild disease activity. Finally, Quantose IR index predictive value would need to be evaluated in large-scale longitudinal studies.

\section{Conclusions}

In conclusion, in this exploratory study, patients with SLE had a high IR index as assessed by the 
metabolomic profile. This is the first study to evaluate IR in SLE patients using a metabolomic profile. IR was found to be common in those SLE patients with a higher BMI and hypertension.

\section{Acknowledgments}

The authors express their gratitude for the support received from the Vice Rector Office for Research and Postgraduate Education (VIEP) at Benemérita Universidad Autónoma de Puebla, and from the National Council for Science and Technology (Conacyt).

\section{Funding}

This project was funded in part by the Mexican Institute of Social Security with the support of a scholarship for master's degree student.

\section{Conflict of Interests}

The authors declare that they have no conflicts of interest.

\section{Ethical disclosures}

Protection of human and animal subjects. The authors declare that the procedures that were followed adhered to the ethical standards of the responsible committee for experimentation on human beings and were in agreement with the World Medical Association and the Declaration of Helsinki.

Confidentiality of data. The authors declare that they have followed the protocols of their work center on the publication of patient data.

Right to privacy and informed consent. The authors have obtained informed consent from the patients and/or subjects referred to in the article. This document is in the possession of the corresponding author.

\section{References}

1. Tso TK, Huang WN. Elevation of fasting insulin and its association with cardiovascular disease risk in women with systemic lupus erythematosus. Rheumatol Int. 2009;29:735-42.
2. Kuo C-Y, Tsai TY, Huang YC. Insulin resistance and serum levels of adipokines in patients with systemic lupus erythematosus: a systematic review and meta-analysis. Lupus. 2020;29:1078-84.

3. Parker B, Urowitz MB, Gladman DD, Lunt M, Bae S-C, Sanchez-Guerrero J, et al. Clinical associations of the metabolic syndrome in systemic lupus erythematosus: data from an international inception cohort. Ann Rheum Dis. 2013;72:1308-14.

4. Petrie JR. Evidence-based estimation of insulin resistance. Diabetologia. 2014;57:1743-5

5. Yang G, Li C, Gong Y, Fang F, Tian H, Li J, et al. Assessment of insulin resistance in subjects with normal glucose tolerance, hyperinsulinemia with normal blood glucose tolerance, impaired glucose tolerance, and newly diagnosed type 2 diabetes (Prediabetes Insulin Resistance Research). J Diabetes Res. 2016;2016:9270768.

6. Matthews DR, Hosker JP, Rudenski AS, Naylor BA, Treacher DF, Turner RC. Homeostasis model assessment: insulin resistance and beta-cell function from fasting plasma glucose and insulin concentrations in man. Diabetologia. 1985;28:412-9.

7. Nicholson JK, Lindon JC. Systems biology: Metabonomics. Nature. 2008;455:1054-6.

8. Cobb J, Gall W, Adam K-P, Nakhle P, Button E, Hathorn J, et al. A novel fasting blood test for insulin resistance and prediabetes. J Diabetes Science Technology. 2013;7:100-10.

9. Tripathy D, Cobb JE, Gall W, Adam K-P, George T, Schwenke DC, et al. A novel insulin resistance index to monitor changes in insulin sensitivity and glucose tolerance: the ACT NOW study. J Clin End Met. 2015; $100: 1855-62$

10. Wu T, Xie C, Han J, Ye Y, Weiel J, Li Q, et al. Metabolic disturbances associated with systemic lupus erythematosus. PloS One. 2012;7:e37210.

11. Guleria A, Pratap A, Dubey D, Rawat A, Chaurasia S, Sukesh E, et al. NMR based serum metabolomics reveals a distinctive signature in patients with Lupus Nephritis. Scientific Rep. 2016;6:35309.

12. Hochberg MC. Updating the American College of Rheumatology revised criteria for the classification of systemic lupus erythematosus. Arthritis Rheum. 1997;40:1725.

13. Gladman DD, Ibanez D, Urowitz MB. Systemic lupus erythematosus disease activity index 2000. J Rheumatol. 2002;29:288-91.

14. Gladman D, Ginzler E, Goldsmith C, Fortin P, Liang M, Urowitz M, et al. The development and initial validation of the Systemic Lupus International Collaborating Clinics/American College of Rheumatology damage index for systemic lupus erythematosus. Arthritis Rheum. 1996;39:363-9.

15. Grundy SM, Cleeman JI, Daniels SR, Donato KA, Eckel RH, Franklin BA, et al. Diagnosis and management of the metabolic syndrome: an American Heart Association/National Heart, Lung, and Blood Institute Scientific Statement. Circulation. 2005;112:2735-52.

16. Cobb J, Eckhart A, Motsinger-Reif A, Carr B, Groop L, Ferrannini E. Hydroxybutyric acid is a selective metabolite biomarker of impaired glucose tolerance. Diabetes Care. 2016;39:988-95

17. Suhre K, Meisinger C, Doring A, Altmaier E, Belcredi P, Gieger C, et al. Metabolic footprint of diabetes: a multiplatform metabolomics study in an epidemiological setting. PloS One. 2010;5:e13953.

18. Gall WE, Beebe K, Lawton KA, Adam K-P, Mitchell MW, Nakhle PJ, et al. Alpha-hydroxybutyrate is an early biomarker of insulin resistance and glucose intolerance in a nondiabetic population. PloS One. 2010;5:e10883.

19. Ferrannini E, Natali A, Camastra S, Nannipieri M, Mari A, Adam K-P, et al. Early metabolic markers of the development of dysglycemia and type 2 diabetes and their physiological significance. Diabetes, 2013; 62:1730-7.

20. Afshin A, Forouzanfar MH, Reitsma MB, Sur P, Estep K, Lee A, et al. Health effects of overweight and obesity in 195 countries over 25 years. N Engl J Med. 2017;377:13-27.

21. Lozovoy MAB, Simao ANC, Oliveira SR, Iryioda TM V, Panis C, Cecchini $\mathrm{R}$, et al. Relationship between iron metabolism, oxidative stress, and insulin resistance in patients with systemic lupus erythematosus. Scand J Rheumatol. 2013;42:303-10.

22. Wang TJ, Larson MG, Vasan RS, Cheng S, Rhee EP, McCabe E, et al. Metabolite profiles and the risk of developing diabetes. Nature Med. 2011;17:448-53.

23. Ruiz-Arguelles A, Mendez-Huerta MA, Lozano CD, Ruiz-Arguelles GJ. Metabolomic profile of insulin resistance in patients with multiple sclerosis is associated to the severity of the disease. Mult Scler Relat Disord. 2018;25:316-21. 